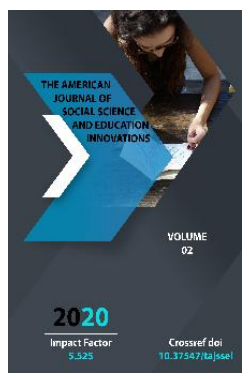

\title{
Khorezm Literary Environment In The Works Of V.V.Bartold
}

Adambaeva Nargiza Kadambaevna

Tashkent Medical Academy Urgench Branch, Uzbekistan

Journal Website: http://usajournalshub.c om/index,php/tajssei

\section{ABSTRACT}

In our rapidly developing society, scientific and literary thinking is being renewed day by day, while the role of literature plays a crucial role in the spiritual development of our people, society and its development.

\section{KEYWORDS}

Development, literary, day, society.

\section{INTRODUCTION}

There On June 20, 2011, the President of the Republic of Uzbekistan made a decree "On Establishment of Center for Study of Cultural Rationes of Uzbekistan at the Cabinet of Ministers of the Republic of Uzbekistan". This document was welcomed by our people, including the intellectuals. This decision is a logical continuation of the complex measures undertaken on studying historical and cultural monuments and the Decree of the President of the Republic of Uzbekistan "On Measures to Further Improve the Preservation, Research and Advocacy of Old Writing Sources" in May this year, not only in our country but also abroad to preserve and educate our rich spiritual heritage as an apple of the eye. In addition, the resolution provides a scientifically-theoretically critical study of 
foreign orientalists who have studied the culture, history and literature of our people and, as a consequence, they offer a wider range of possibilities and opportunities for studying Turkish-literary sources used in their time[1.3].

In response, young researchers have to study the cultural heritage of our country, in particular the rarities and manuscripts created by our ancestors, as well as studying and conveying to our people the high recognition and researches of foreign orientalists on our spiritual and cultural heritage.

\section{MATERIALS AND METHODS}

We can regard it as an honor and acknowledgment of an ethnicity's interest in the study of the literary environment of another nation by its cultural heritage. It is also worth noting that Russian scholars have their own research on the study of the unique works of Uzbekistan. Epistolary sources in the archives refer to the period of the scientificliterary environment: ideas of exchange, evaluation, review, criticism, literary-aesthetic views, and most importantly, the Turkish manuscripts they used. It is possible to note the correspondence of A.Samoylovich, V.V.Bartold, I.Yu.Krachkovskiy, V.Gordlevsky, N.P.Ostroumov, A.Semenov and other scientists [1.4].

The greatest orientalist, whose work has largely retained its significance to the present, is the outstanding Russian scientist, Academician V. V. Bartold, who devoted his life to the study of the past, countries and peoples of Central Asia and the East. The abstracted work is devoted to the study of V.V Bartold's contribution to the development of the history of Khorezm, one of the most important historical and cultural regions of the East.

From 1927 to 1930, Barthold was engaged in describing manuscripts regularly, as a rule, twice a week, on Mondays and Thursdays, visiting the Public Library. In total, about 500 manuscripts were described: Arabic ("New Series"); Collect. I. V. Khanykova; Collect. AS Firkovich; Persian-Tajik. ("Persian New Series"); Turkic-speaking ("Turkish new series"). The works of Barthold were of exceptional value, since they allowed the introduction into scientific circulation of unknown earlier materials. Judging by the five-year plan drawn up by Barthold in 1929, he intended to devote cataloging to several years. Death prevented him from completing this work.

In the VIII volume of the works of V.V.Bartold, works are devoted to Arabic, Persian and Turkic-speaking written sources. Work on the manuscript sources fascinated and attracted V.V. Bartold also with his search side. In the Autobiography, he remarked: ... when reading the manuscripts, you often experience the same pleasure of a person discovering a new world, as in the production of excavations in place of old cities "[1.p.5].

\section{RESULT AND DISCUSSION}

Excellent philological preparation allowed V.V. Bartold equally freely to operate sources in Arabic, Persian and Turkic languages, which was one of the most powerful aspects of his scientific activity.

Central Asia was the main place in the works of V.V. Bartold. In this regard, he paid much attention to the searches and study of written monuments of its history and culture, and also vividly responded to any research or 
publication of the primary source related to the sphere of his scientific interests. These articles and reviews are quite diverse on the subject and concern both historical monuments and works on the history of the language, literature and culture of the peoples of Central Asia. We would like to highlight four of his works, which testify to the scientist's interest in very few and rare historical sources, historical and cultural and literary monuments in the Turkic languages. This is primarily an article "The Monument to the Time of Propagation of Islam in Central Asia", dedicated to an anonymous Turkic tafsir (commentary on the Koran), whose manuscript was acquired in 1914 for the Asian Museum by A.Z. Validov. The language of tafsir, proceeding from its peculiarities, V.V. Bartold considers archaic and close to the language of "Kisas al-anbiya" Rabguzi, but heterogeneous and modernized in the Timurid epoch. The article "The Manuscript of Zamakhshari with the Old Turkic Glosses" is devoted to the description of the list of the works of Zamakhshari "Mukaddimat al-adab", which V.L.Vyatkin presented to the Asian Museum in 1897.According to V.V. Bartold, glosses are of interest not only from the point of view of language but also the history of culture. The article "The New Manuscript by the Uighur font in the British Museum" examines a manuscript from the new acquisitions of the British Museum, containing poems by Lutfi in the Old Uzbek language and Mukhabbat-nomaof Khorezmi on the literary Turk of the Volga region. Finally, the fourth article, "A New Source on the History of Khorezm" contains a description of a unique work on the history of Khorezm in the 19th century. Tavarikh-iHarezmshahiyaof Baba-Jan Mangyt, completed by compiling in 1864 a list of works was discovered by V.V.Barthold in 1929 in the Prussian State Library in Berlin[1.65].

\section{CONCLUSION}

In short we can say that our Uzbek literary cultural heritage is so rich and unique that world literary scholars have been studying for centuries. We must study young people and present them to the public.

\section{REFERENCES}

1. Bartold V.V. Sochineniya. Tom II. Chast 2 // Moskow. Nauka. 1964

2. Karimov. Yuksakmanaviyatyengilmaskuch. -Tashkent: Manaviyat, 2008. - P.48.

3. Decree of May 13, 2016 No. UP-4797 "On the organization of the Tashkent State University of Uzbek Language and Literature named after AlisherNavoi."

4. Hallieva G. Studying of the Uzbek Classical Literature in the Russian Literary Criticism of the XX Century // Young Scientist.- USA, 2016. Vol.2. P.133.

5. Erkinov A. Molitvizaiprotivsarya.// "Istoricheskiyvestnik". - Runivers.

6. HakimovM.Xalqimizmanaviyboyiliginin gnodirnamunalari. "Tilvaadabiyottalimi". Toshkent - No. 7 - 2017 - P. 5 